DEPARTMENT OF THE INTERIOR

UNITED STATES GEOLOGICAL SURVEY

\title{
GROUND MAGNETIC STUDIES ALONG A REGIONAL SEISMIC- REFLECTION PROFILE ACROSS BARE MOUNTAIN, CRATER FLAT AND YUCCA MOUNTAIN, NEVADA
}

\author{
by
}

\section{V.E. Langenheim and D.A. Ponce}

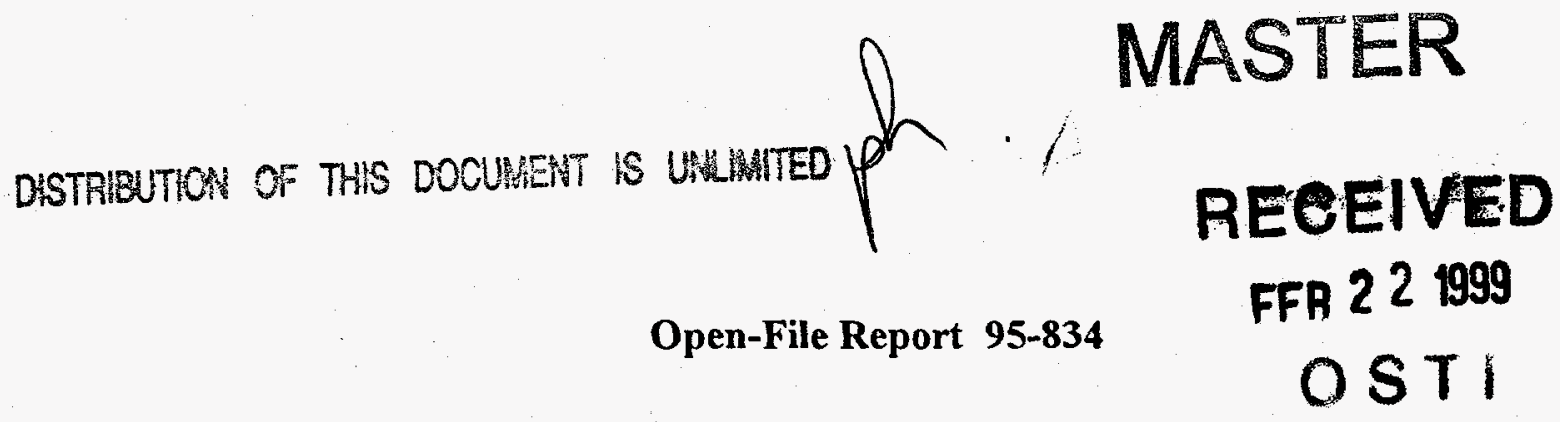

Prepared in cooperation with the

Nevada Operations Office

U.S. Department of Energy

(Interagency Agreement DE-AI08-92NV10874)

This report is preliminary and has not been reviewed for conformity with U.S. Geological Survey editorial standards or with the North American Stratigraphic Code. Any use of trade, firm, or product names is for descriptive purposes only and does not imply endorsement by the U.S. Government.

Menlo Park, California 


\section{DISCLAIMER}

This repor was prepared as an account of work sponsored by an agency of the United States Government. Neither the United States Governmeot nor any agency tbereof, nor any of their employees, makes any warranty, express or implied, or assumes any legal liability or responsibility for the accuracy, coropletereses or usefulness of any information, apparatus, product, or process disciosed, or represents that its use would not infringe privately owned rights. Refereace berein to any specific commercial product, process, or service by trade name, tradernark manufac. turer, or otherwise does not necessarily constitute or imply its endorsenent, recom. mendation, of favoring by the United States Government or any ugeacy thereof. The views and opinions of authors expressed herein do not necessarily srate or reflect those of the United States Governmeat or any agency thereof. 


\section{DISCLAIMER}

Portions of this document may be illegible in electronic image products. Images are produced from the best available original document. 


\section{U.S. DEPARTMENT OF THE INTERIOR BRUCE BABBITT, Secretary \\ U.S. Geological Survey \\ Gordon P. Eaton, Director}

The use of trade, product, industry, or firm names is for descriptive purposes only and does not imply endorsement by the U.S. Government.

For additional information, write to:

Chief, Earth Sciences Investigation Program

Yucca Mountain Project Branch

U.S. Geological Survey

Box 25046, Mail Stop 421

Denver Federal Center

Denver, CO 80225
Copies of this report can be purchased from:

U.S. Geological Survey

Branch of Information Services

Box 25286

Denver, Colorado 80225-0286 


\author{
DEPARTMENT OF THE INTERIOR \\ UNITED STATES GEOLOGICAL SURVEY
}

\title{
GROUND MAGNETIC STUDIES ALONG A REGIONAL SEISMIC- REFLECTION PROFILE ACROSS BARE MOUNTAIN, CRATER FLAT AND YUCCA MOUNTAIN, NEVADA
}

\author{
by
}

V.E. Langenheim and D.A. Ponce ${ }^{1}$

IU.S. Geological Survey, 345 Middlefield Road, Mail Stop 989, Menlo Park, CA 94025

Open-File Report 95-834

Menlo Park, California

1995 


\section{TABLE OF CONTENTS}

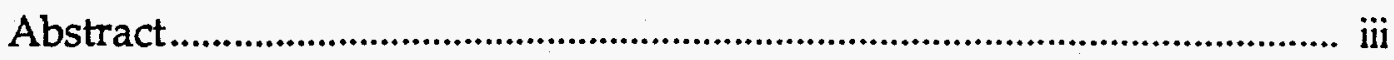

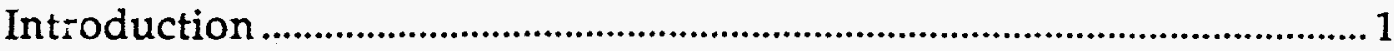

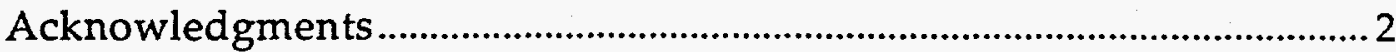

Geologic Setting and General Geology ………....................................... 2

Previous Work ........................................................................................................

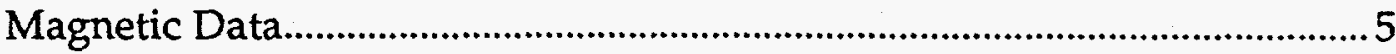

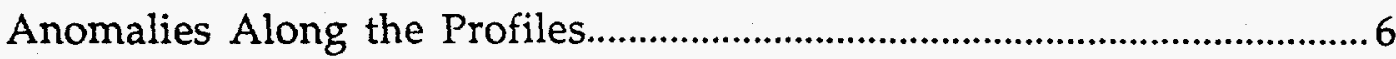

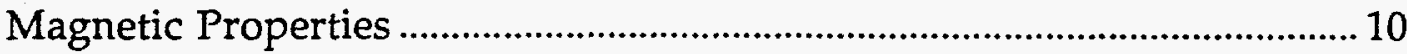

Modeling.............................................................................................................. 11

Source of the Magnetic High over Crater Flat ........................................... 14

Bare Mountain Fault..................................................................................... 16

Faulting in Crater Flat and Yucca Mountain ......................................... 17

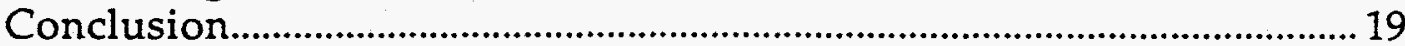

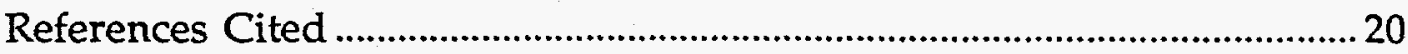

Tables

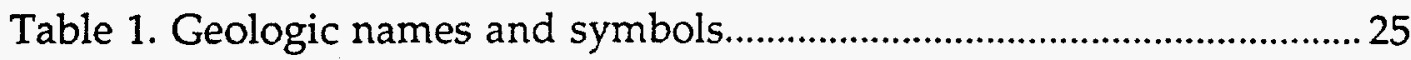

Table 2. Magnetic properties of rock units used in models......................... 26

Table 3. Thickness in meters of rock units in various drill holes........... 27

\section{Illustrations}

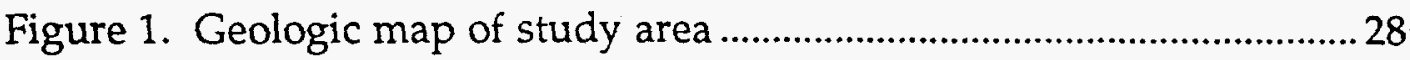

Figure 2. Aeromagnetic map of study area .................................................. 29

Figure 3. Ground magnetic profile along Line 2 ........................................30

Figure 4a. Ground magnetic data about $100 \mathrm{~m} \mathrm{SE}$ of Line 2........................31

Figure $4 \mathrm{~b}$. Ground magnetic data about $100 \mathrm{~m}$ NW of Line 2 .....................32

Figure 5. Theoretical magnetic model across N-S fault................................33

Figures 6a-c. Magnetic models along Line 2 ..............................................34-36 


\begin{abstract}
Ground magnetic data were collected along a 26-km-long regional seismicreflection profile in southwest Nevada that starts in the Amargosa Desert, crosses Bare Mountain, Crater Flat and Yucca Mountain, and ends in Midway Valley. Parallel ground magnetic profiles were also collected about $100 \mathrm{~m}$ to either side of the western half of the seismic-reflection line. The magnetic data indicate that the eastern half of Crater Flat is characterized by closelyspaced faulting (1-2 km) in contrast to the western half of Crater Flat.

Modeling of the data indicates that the Topopah Spring Tuff is offset about $250 \mathrm{~m}$ on the Solitario Canyon fault and about $50 \mathrm{~m}$ on the Ghost Dance fault. These estimates of fault offset are consistent with seismic-reflection data and geologic mapping. A broad magnetic high of about 500-600 nT is centered over Crater Flat. Modeling of the magnetic data indicates that the source of this high is not thickening and doming of the Bullfrog Tuff, but more likely lies below the Bullfrog Tuff. Possible source lithologies for this magnetic high include altered argillite of the Eleana Formation, Cretaceous or Tertiary intrusions, and mafic sills.
\end{abstract}




\section{INTRODUCTION}

Understanding the structural framework of southwest Nevada is essential for assessing the seismic hazard of a proposed high-level radioactive waste repository site at Yucca Mountain. Three main hypotheses have been proposed to explain the structure at Yucca Mountain and vicinity and, in particular, the formation of Crater Flat, an elliptical, deep basin just west of the crest of Yucca Mountain: (1) volcano-tectonic depression or caldera (Snyder and Carr, 1984), (2) detachment faulting (Hamilton, 1988), and (3) graben or pull-apart faulting (Fridrich and others, 1994). Geophysical data, especially gravity data, have been used to support two of these hypotheses, namely the caldera hypothesis (Snyder and Carr, 1984), and the detachment faulting mechanism (Oliver and Fox, 1993). In particular, these gravity models have focussed on the geometry of the Bare Mountain fault, a structure that places folded and faulted Precambrian and Paleozoic sedimentary rocks of Bare Mountain in juxtaposition with the Tertiary and Quaternary alluvial deposits of Crater Flat (Monsen and others, 1992). The Bare Mountain fault has generally been linked geometrically to faults underlying Yucca Mountain, faults that are hidden under a thick volcanic pile. Langenheim (1995a) demonstrated that modeling of gravity data alone does not rule out any of the hypotheses thus proposed for the structure of Yucca Mountain, but can provide geometries that can be tested with other data and vice versa. In the fall of 1994, the U.S. Geological Survey conducted two seismic-reflection profiles across Crater Flat and Yucca Mountain (lines 2 and 3, fig. 1) to image the underlying structure. Ground magnetic and gravity data were also collected along these profiles. This report presents ground magnetic data collected along the longer of the two seismic traverses (Line 2; 
Brocher and others, 1995) to help constrain interpretations of the seismic data, characterize faulting, and locate buried volcanic and igneous bodies.

\section{ACKNOWLEDGMENTS}

R.F. Sikora, C.W. Roberts, and P.F. Halvorson of the U.S. Geological Survey assisted in the collection of ground magnetic data presented in this report.

\section{GEOLOGIC SETTING AND GENERAL GEOLOGY}

The area of interest lies along the southern margin of the southwest Nevada volcanic field which produced voluminous and widespread ash-flow sheets from more than six major calderas that range in age from about 15 to 7.5 Ma (Sawyer and others, 1994); the study area also lies within the Walker Lane belt (Carr, 1984). The Walker Lane belt is a northwest-trending zone of diverse topography and structure that has undergone substantial lateral shear. Yucca Mountain forms the eastern edge of Crater Flat and lies along the eastern margin of a north-trending structural trough called the KawichGreenwater rift (Carr, 1990). This tectono-volcanic rift represents a pull-apart or stepped zone of rifting within the larger Walker Lane belt and is near or parallel to a zone of Pliocene and Quaternary volcanism called the Death Valley-Pancake Range basalt belt (Carr, 1984).

The geologic units that underlie the study area consist of Precambrian and Paleozoic rocks, a series of Miocene ash-flow tuffs interbedded with relatively thin ash-fall and reworked tuffs, and late Tertiary and Quaternary surficial deposits and basalt flows. Pre-Cenozoic sedimentary and metamorphic rocks in the study area are predominantly limestone and dolomite, with lesser amounts of argillite, quartzite, and marble (U.S. Geological Survey, 1984). Paleozoic sedimentary rocks are exposed in the northeastern part of the study 
area at Calico Hills (McKay and Williams, 1964) and at Bare Mountain (Monsen and others, 1992). Only one drill hole in the vicinity of Yucca Mountain has penetrated pre-Tertiary units; drill hole UE-25 p\#1 (p\#1, fig. 1) penetrated dolomite at a depth of 1,244 $\mathrm{m}$ (Carr and others, 1986).

The stratigraphic names of the Cenozoic volcanic rock units which occur at Yucca Mountain have recently undergone revision (Sawyer and others, 1994), elevating formation names to group and members to formations.

These revisions will be followed throughout this report (table 1). In ascending order, the Cenozoic volcanic units are: (1) older ash-flow tuffs, (2) Lithic Ridge Tuff, (3) Crater Flat Group, (4) Calico Hills Formation, (5) Paintbrush Group, and (6) Timber Mountain Group. The Crater Flat Group is composed of the Tram, Bullfrog, and Prow Pass Tuffs, the Paintbrush Group is composed of the Topopah Spring, Pah Canyon, Yucca Mountain, and Tiva Canyon Tuffs, and the Timber Mountain Group is composed of the Rainier Mesa and Ammonia Tanks Tuffs.

\section{PREVIOUS WORK}

Total-field magnetic data from 3 separate surveys (U.S. Geological Survey, 1979; Langenheim and others, 1991; Grauch and others, 1993) were used to construct the aeromagnetic map shown in figure 2. The data were smoothed by upward continuation (Cordell, 1985) to an effective height of $305 \mathrm{~m}$ (1000 ft) above the land surface.

Previous studies of the magnetic field in the Yucca Mountain area have indicated that the source of most of the magnetic anomalies in the region are volcanic rocks (Bath, 1968; Bath and Jahren, 1984). One exception is an intense magnetic high present over Calico Hills (fig. 2). The source of the high is altered argillite of the Mississippian-Upper Devonian Eleana 
Formation (Baldwin and Jahren, 1982). Bath and Jahren (1984) proposed that an underlying intrusion caused the alteration. The magnetic high at Calico Hills extends west over the northern part of Yucca Mountain, suggesting that highly magnetic argillite (and its associated intrusion) is present at depth below Yucca Mountain and northern Crater Flat (Bath and Jahren, 1984).

Another large aeromagnetic high of about $250 \mathrm{nT}$ is centered over Crater Flat (fig. 2). Carr (1984, 1990) suggested on the basis of drill holes USW VH-1 and USW VH-2 (VH-1 and VH-2, fig. 1, respectively) that the source of this broad magnetic high is doming and thickening of the normally polarized Bullfrog Tuff. However, based on modeling of a profile of gridded aeromagnetic values nearly coincident with Line 2, Langenheim (1995a) concluded that Carr's (1990) proposed doming and increase in thickness of the Bullfrog Tuff were not sufficient to account for the amplitude of the magnetic high. She suggested that the source of the high is an intrusion.

Other geophysical studies in the area include five seismic refraction profiles carried out at Yucca Mountain and vicinity (Mooney and Schapper, 1995). One of these profiles is nearly coincident with the newly acquired geophysical profile in the vicinity of Yucca Mountain. The refraction data, in conjunction with gravity data (Snyder and Carr, 1984; Langenheim, 1995a), indicate that the basin fill of Crater Flat reaches thicknesses of 3 to $4 \mathrm{~km}$. The refraction data (Mooney and Schapper, 1995) had difficulties distinguishing shallow pre-Tertiary basement from volcanic fill, especially at drill hole UE-25 p\#1, because of the sensitivity of seismic velocities to fracturing and brecciation.

Interpretation of previous seismic-reflection work in the vicinity of Yucca 
Mountain proved to be notoriously difficult until the acquisition of an eastwest seismic reflection profile (coincident with Mooney and Schapper's Amargosa Valley seismic refraction profile) $20 \mathrm{~km}$ south of Yucca Mountain (Brocher and others, 1993). The Amargosa Valley seismic reflection profile successfully imaged faulting and basalt flows. On a more local scale, highresolution seismic-reflection work on Yucca Mountain has imaged the Ghost Dance fault (Majer and Karageorgi, 1994).

The success in the acquisition and interpretation of line AV-1 led to the acquisition of regional seismic lines 2 and 3 in the fall of 1994. In addition to the seismic-reflection data and ground magnetic data collected along the profiles, gravity data were collected (Johnson and others, 1995). Description of the seismic-reflection data collected along and isostatic gravity models of lines 2 and 3 are presented in Brocher and others (1995).

\section{MAGNETIC DATA}

Ground magnetic data were collected with the sensor $2.4 \mathrm{~m}$ above the surface along the entire length of the seismic reflection profile (line 2, fig. 1). The line begins at station 101 west of Bare Mountain at Ashton and ends at st.ation 1133 near Exile Hill in Midway Valley. Surveyed seismic station flags (25 $\mathrm{m}$ apart) provided the basis of the magnetic station locations. Locations of magnetic stations between surveyed seismic stations were determined by interpolation using the number of paces and the surveyed distances between the seismic stations. The nominal magnetic station spacing was 15 paces or about $12 \mathrm{~m}$. The maximum magnetic station spacing was 30 paces or about 25 $\mathrm{m}$, corresponding to the spacing between the surveyed locations of seismic stations. The minimum spacing between magnetic data points was 1 pace or about $1 \mathrm{~m}$. In addition to data collected along the seismic profile, parallel 
ground magnetic profiles offset approximately $100 \mathrm{~m}$ to either side of the seismic profile were collected along the western half of the profile. The two parallel ground magnetic profiles were located by pacing and thus are only approximately located (estimated $+/-10 \mathrm{~m}$ ). The magnetic profile located northwest of the seismic line begins at st. 101 and ends at station 645 whereas the profile to the southeast begins at station 101 and ends at station 641. Data were not collected between stations 539 and 565 on the northwest line because of extremely rapid variations in magnetic intensity caused by proximity to randomly oriented, highly magnetic float of basaltic rocks from Red Cone.

A model G-816 Geometrics portable proton precession magnetometer and G-826A base station magnetometer were used to collect data. Because the anomalies of interest were believed to be small $(20$ to $50 \mathrm{nT})$ and the profile line was long $(26 \mathrm{~km})$, either a base station magnetometer was used or a temporary base along the traverse was periodically reoccupied during the survey to measure corrections for diurnal variations of the Earth's magnetic field. The magnetic measurements were corrected for diurnal variations and are total magnetic field values. Magnetic observations are accurate to about 1 $\mathrm{nT}$ (Dobrin and Savit, 1988). The profile of the magnetic data along the seismic-reflection line is shown on figure 3. The parallel ground magnetic profiles are shown in figures $4 \mathrm{a}$ and $4 \mathrm{~b}$ (southeast and northwest of the seismic-reflection line, respectively).

\section{ANOMALIES ALONG THE PROFILE}

Seismic line 2 trends northwest from the Amargosa Desert across Yucca Mountain to Midway Valley (fig. 1). In general, the ground magnetic anomalies correspond well to anomalies on the aeromagnetic map (fig. 2). The magnetic data along the regional seismic line can be divided into four 
different structural domains: (1) Amargosa Desert (stations 101 to 285), (2)

Steve's Pass (stations 285 to 330), (3) Crater Flat (stations 330 to 910), and (4)

Yucca Mountain (east of station 910). The magnetic field values in the Amargosa Desert segment of line 2 are relatively flat (less than $50 \mathrm{nT}$ variation), except for anomalies at station 150 to 200 and station 210-250 (fig. 3). The flatness of the magnetic field, apart from the anomalies at station 150 and station 210 , reflects the absence of vertical offsets or rapid changes in thickness of the buried volcanic units. An anomaly of $600 \mathrm{nT}$ at station 150 is probably caused by shallowly buried volcanic rocks. The steep gradient of the anomaly suggests that the top of the volcanic rocks is at a depth of less than $100 \mathrm{~m}$. The relative position of the high along the three ground magnetic profiles indicates that the edge of the source trends approximately northsouth, consistent with the trend of its corresponding aeromagnetic anomaly (fig. 2).

Most of the intense fluctuations in magnetic values from station 210 to station 250 are caused by powerlines and fences. However, these fluctuations mask a small-amplitude magnetic high and low seen in the aeromagnetic data (fig. 2), that are most likely caused by shallow volcanic rocks. Because of the interference of anomalies caused by manmade sources, it is difficult to characterize the anomaly and it is not possible to estimate a maximum depth to the top of the volcanic rocks at this location; however, just to the south of station 210 are outcrops of Ammonia Tanks Tuff (Swadley and Carr, 1987). In addition, a lithologic log for a line 2 shot-hole near this location indicates volcanic tuff at shallow depth (Brocher and others, 1995, table 8). At station 230, seismic-reflection data indicate a structural bump in the pre-Tertiary contact (Brocher and others, 1995) that may be related to the source of the 
magnetic anomaly. Despite the interference from manmade sources, it appears that the edge of the source trends approximately northwest-southeast, consistent with the trend of its corresponding aeromagnetic anomaly (fig. 2).

For the Steve's Pass segment of the profile (stations 285 to 330), all three ground magnetic profiles are characterized by little variation in magnetic field values (fig. 3). The extreme flatness of the magnetic field is expected and reflects the weakly to non-magnetic character of the underlying and exposed Precambrian and Paleozoic rocks. Magnetic susceptibility measurements (Langenheim, 1995a) confirm that only one formation of this sequence (metapelite of the Wood Canyon Formation) is magnetic whereas the other pre-Tertiary formations at Bare Mountain are essentially non-magnetic. Mapping by Monsen and others (1992) indicates that the Wood Canyon Formation is not exposed along the profiles.

The ground magnetic values for Crater Flat (stations 330-910) show intense variations in the vicinity of Little Cones (stations 400-460) and Red Cone (stations $545-570$ ). These rapid variations are caused by close proximity of the magnetometer to randomly oriented, strongly magnetic basalt float. All three profiles show strong fluctuations in the vicinity of Little Cones; only the profile $100 \mathrm{~m}$ southeast of the seismic line is far enough removed from the basaltic debris of Red Cone to show a small magnetic high (less than 100 $\mathrm{nT}$ ) that is most likely an edge effect caused by the reversely magnetized basalt of Red Cone. At stations 650 to 670 , very shallowly buried basalt at a depth of $30 \mathrm{~m}$, most likely an extension of $3.7 \mathrm{Ma}$ basalt outcrops just to the south of the profile (Swadley and Parrish, 1988), probably accounts for shortwavelength anomalies with amplitudes of up to $800 \mathrm{nT}$ less than $1 \mathrm{~km}$ east of drill hole USW VH-1. 
A magnetic high with a total amplitude of about $350 \mathrm{nT}$ between stations 350 and 400 (fig. 3) is located at or near the location of the range-front fault of Bare Mountain as inferred from gravity and seismic reflection data (Brocher and others, 1995). The strike of the anomaly is approximately northnorthwest based on the relative position of the anomaly on the three parallel magnetic profiles. The gradient of the anomaly suggests that the top of the causative body is within the Tertiary volcanic and sedimentary section rather than within the pre-Tertiary basement. The only pre-Tertiary candidate for producing this anomaly is the Wood Canyon Formation (see above); however, it is unlikely that Wood Canyon Formation is in the shallow subsurface in this area because outcrops of nonmagnetic Stirling Quartzite are located just to the east of the profile (Monsen and others, 1992). The aeromagnetic map suggests that the high may be related to a strong positive magnetic anomaly just south of Little Cones. Based on modeling by Langenheim (1995b), the source of the aeromagnetic high is a normallypolarized basaltic center whose top surface is buried probably no deeper than $300 \mathrm{~m}$. The age of the buried basaltic center is not known, but is probably Miocene or younger (Langenheim, 1995b). Other possible candidates for the source of the magnetic high include the normally polarized Ammonia Tanks and Topopah Spring Tuffs.

Ground magnetic values indicate a broad magnetic high of about $500-600$ $\mathrm{nT}$ centered in Crater Flat near drill hole USW VH-1. The magnetic high is about $10 \mathrm{~km}$ wide. Apart from the rapid variations in magnetic values due to Little Cones and Red Cone, the western half of this high is smooth. In contrast to the smooth character of the magnetic field of the western half of Crater Flat, the magnetic field of the eastern half of Crater Flat (stations 700- 
950 ) is characterized by somewhat regularly spaced magnetic highs and lows.

The anomalies have amplitudes of up to $200 \mathrm{nT}$ and widths of $0.5 \mathrm{~km}$ to $1 \mathrm{~km}$ and are spaced 1 to $2 \mathrm{~km}$ apart. The spacing between the anomalies appears to decrease as the profile approaches Yucca Mountain. These anomalies are similar in character to the magnetic anomaly caused by vertical offset of the Topopah Spring Tuff (Tpt on fig. 5). The short-wavelength anomalies between station 850 and station 950 may also reflect the proximity of the profile to outcrops of Tiva Canyon Tuff just to the north of the profile.

The ground magnetic field of the Yucca Mountain structural domain begins with the large magnetic high and accompanying low at station 950 to station 990 caused by the Solitario Canyon fault. The amplitude of the anomaly is over $800 \mathrm{nT}$. East of the crest of Yucca Mountain, the magnetic values indicate very short-wavelength anomalies with an average amplitude of about $100 \mathrm{nT}$. A few anomalies reach amplitudes of $400 \mathrm{nT}$ (for example, between station 1075 and station 1100). The roughness of the field probably reflects terrain effects and proximity to magnetic float, but may also indicate faulting. Although the signature of the Ghost Dance fault along line 2 is somewhat obscured by the short-wavelength character of the ground magnetic field east of Yucca Mountain, figure 3 shows clearly that offset on the Ghost Dance fault does not produce an anomaly comparable to that associated with the Solitario Canyon fault, a fault with offsets of hundreds of meters of the Topopah Spring Tuff (Bath and Jahren, 1985; Ponce and Langenheim, 1995).

\section{MAGNETIC PROPERTIES}

Knowledge of the magnetic properties of the rocks in the study area is a very useful constraint for detailed modeling of magnetic data. Magnetic 
properties of the various volcanic units in the Yucca Mountain area were described by Bath (1968), Bath and Jahren (1985), Rosenbaum and Snyder (1985), and Champion (1991). A summary of the physical properties used in the magnetic model is shown in table 2 .

Previous studies have shown that remanent magnetization is responsible for causing most of the magnetic anomalies present within the Nevada Test Site and vicinity (Bath, 1968; Bath and Jahren, 1984). In particular, many of the north-trending, linear magnetic anomalies are caused by vertical offset of the moderately to highly magnetic, normally polarized Topopah Spring Tuff (Tpt, fig. 5; Bath and Jahren, 1984). In general magnetic highs occur over the upthrown block. The averaged values listed in Table 2 do not take into account the widely varying magnetization in some units (Bath, 1968; Rosenbaum and Snyder, 1985).

\section{MODELING}

The principal goal of magnetic studies is to detect and quantify changes in magnetic properties at depth. To translate the observed magnetic anomalies into a meaningful geologic picture of the subsurface often requires modeling. The interpretation of magnetic data can yield nonunique solutions because substantially different geometrical models can provide an associated field that closely matches the observed field. However, many of these models can be eliminated because they give geologically unrealistic geometries. Some of these models can also be eliminated because of other information, such as physical property data, geologic mapping, stratigraphic thickness, drillhole data, and other geophysical data.

Although geophysical modeling can be used to delineate small-scale 
features, the required detailed magnetic property information is not available to resolve the details of the magnetic features seen in the ground magnetic data. Because of the overriding effect of the Topopah Spring Tuff (Tpt, fig. 5), inferred faults or structures may not be very well constrained in the magnetic models. The two-dimensional models may not adequately account for the three-dimensionality of the underlying structure and abrupt changes in magnetic properties within a given rock unit may make some models poorly constrained.

Keeping these above-mentioned caveats in mind, three two-dimensional models of the ground magnetic data were created (figs. 6a-c). Direction and magnitude of magnetization assigned to the various rock units are given in table 2. Exceptions to the values listed in table 2 are shown on the models. The geometry of the models is constrained by measurements of stratigraphic thickness from nearby drill holes (table 3) and mapped geology (Scott and Bonk, 1984; Monsen and others, 1992; Swadley and Parrish, 1988). The location of the pre-Tertiary contact is based on isostatic residual gravity modeling by Langenheim shown in Brocher and others (1995; fig. 21A). Because no magnetic property contrast has been assigned to the pre-Tertiary contact under Crater Flat, the position of the contact does not affect the results of the model and is shown for completeness of the geologic section.

All three models have a unit representing the $3.7 \mathrm{Ma}$ basalt flow $\left(\mathrm{Tb}^{\mathrm{a}}\right)$ that is based on the strong reflection seen along Line 2 at about $150 \mathrm{~m}$ (Brocher and others, 1995). The characteristics of the reflection are similar to those of buried basalts imaged on a seismic-reflection line in the Amargosa Valley (Brocher and others, 1993; Brocher and others, 1995). The age of this reflection is not known, but could belong to either the $3.7 \mathrm{Ma}$ basalt or $10.5 \mathrm{Ma}$ basalt 
penetrated in drill holes USW VH-1 and USW VH-2 (Carr and Parrish, 1985). The reflection projects up to the surface in the vicinity of drill hole USW VH1, which penetrated basalt at a depth of $29 \mathrm{~m}$ (table 3). Carr and Parrish (1985) attribute an age of 3.8 Ma to the basalt encountered in USW VH-1. Although this basalt flow is thin, it is very magnetic and shallow. The models indicate that its eastern edge would produce a magnetic high of about $250 \mathrm{nT}$ that is observed in the ground magnetic data less than $1 \mathrm{~km}$ east of drill hole USW $\mathrm{VH}-1$. The other basalt flow shown in figures $6 \mathrm{a}-\mathrm{c}$ is based on basalt found in drill hole USW VH-2 at a depth of $360 \mathrm{~m}$ (Carr and Parrish, 1985, table 3) and could correspond to reflections imaged along Line 2 at about this depth (Brocher and others, 1995). The geometry of this basalt flow is poorly constrained by the ground magnetic data. However, the continuity of an aeromagnetic low with a magnitude of up to $150 \mathrm{nT}$ along the western edge of Crater Flat (fig. 2) attributed to the reversely magnetized basalt flow at $360 \mathrm{~m}$ in USW VH-2 suggests that the basalt does indeed underlie line 2.

The mismatch between observed values and calculated values of about $150 \mathrm{nT}$ at the eastern end of Line 2 (fig. 6a) most likely is related to altered argillite of the Eleana Formation. The eastern part of line 2 obliquely crosses an east-west trending gradient in the magnetic field that appears to be an extension of the intense magnetic high at Calico Hills attributed to the argillite of the Eleana (fig. 2). A body representing the altered argillite of the Eleana buried at a depth of $2 \mathrm{~km}$ eliminates the mismatch between observed and calculated values in figures $6 \mathrm{~b}$ and $6 \mathrm{c}$. The magnetization, thickness, and depth of this inferred body are based on models by Bath and Jahren (1984). The mismatch between observed and calculated values of about 100-150 $\mathrm{nT}$ at the western end of Line 2 (figs. $6 a-c$ ) reflects the presence of a reversely- 
magnetized source. A negative aeromagnetic anomaly of about $50 \mathrm{nT}$ is centered over the length of Amargosa Desert; possible sources for this anomaly include reversely-magnetized basalt flows, Tiva Canyon Tuff and the Rainier Mesa Tuff.

Source of the Magnetic High over Crater Flat

All three models share nearly the same geologic structure for the stratigraphic units above the Bullfrog Tuff. They differ mainly in their explanation of the magnetic high centered over Crater Flat. The first model (fig. 6a) is based on Carr's $(1984,1990)$ schematic cross-section across Crater Flat where doming and thickening of the Bullfrog Tuff are the source of the magnetic high. Although the resulting magnetic field produced by the first model (fig. 6a) matches many of the short-wavelength anomalies, moderate (less than double) thickening of the Bullfrog Tuff is inadequate to produce the broad magnetic high centered over Crater Flat. This conclusion is consistent with the modeling of gridded aeromagnetic values by Langenheim (1995a).

The second model (fig. 6b) illustrates that the amount of thickening of the Bullfrog Tuff required to match the observed amplitude of the magnetic high is geologically unreasonable. Figure $6 \mathrm{~b}$ shows that the Bullfrog Tuff not only needs to be $1 \mathrm{~km}$ thick (nearly 10 times the measured stratigraphic thickness of the Bullfrog Tuff in the study area), but also have an average magnetization of $4 \mathrm{~A} / \mathrm{m}$, twice the measured average magnetization listed in table 2. Such a dramatic thickening of the Bullfrog Tuff is highly unlikely, especially since new data suggest that the source of the Bullfrog Tuff does not lie in Crater Flat, as previously proposed by Carr (1984), but in the northwest corner of the Nevada Test Site, some $50 \mathrm{~km}$ away (Sawyer and others, 1994). 
This geometry also produces a calculated field that does not closely fit the observed magnetic field measured east of USW VH-1.

The third model (fig. 6c) places the source of the anomaly below the Bullfrog Tuff. Figure $6 \mathrm{c}$ indicates the broad magnetic high can be caused by a strongly magnetic source within the pre-Tertiary basement, $1-2 \mathrm{~km}$ below the base of the Crater Flat basin fill. The modelled source has a magnetization of $4 \mathrm{~A} / \mathrm{m}$ and is about $3 \mathrm{~km}$ thick. One lithologic candidate for this source is highly magnetic, altered argillite of the Eleana Formation. The argillite exposed at Calico Hills has an measured average magnetic susceptibility of $3.89 \mathrm{~A} / \mathrm{m}$ (Baldwin and Jahren, 1982). Another possible source lithology within the pre-Tertiary basement is a granitic intrusion. If the top of the source were at the base of the basin fill, the magnetization could be as small as $2.7 \mathrm{~A} / \mathrm{m}$, about twice the measured magnetization of the Climax intrusive stock (Bath and others, 1983), but within the range of measured magnetizations for felsic to mafic intrusive rocks (Dobrin and Savit, 1988). A third possible candidate for the source of the anomaly is mafic sills. Brocher and others (1995) found a prominent subhorizontal reflector about $5.0 \mathrm{~km}$ below Crater Flat that they interpret to be caused by mafic sills. Modeling of the magnetic data indicates that the top of the source of the broad magnetic high is probably no deeper than $5 \mathrm{~km}$ and requires very high magnetizations $(10 \mathrm{~A} / \mathrm{m})$. Mafic rock types such as gabbro, diabase or basalt can be characterized by such high magnetizations (Dobrin and Savit, 1988).

Modeling of the magnetic high centered over Crater Flat suggests that Carr's $(1984,1990)$ proposed thickening and doming of the Bullfrog Tuff are insufficient to be the source of the anomaly. Modeling indicates that the source of the high may lie within the pre-Tertiary basement. Possible source 
lithologies within the pre-Tertiary basement include altered Eleana argillite, a Tertiary or Cretaceous granitic intrusion, or mafic sills. Of the three possible source lithologies within the pre-Tertiary basement, the presence of mafic sills below Crater Flat could account for the high seismic velocities (about 6.8 $\mathrm{km} / \mathrm{s}$ ) that Mooney and Schapper (1995) measured beneath Crater Flat. The magnetic data are thus compatible with the interpretation of mafic sills below Crater Flat within the resolution of the seismic-reflection and magnetic data.

\section{Bare Mountain Fault}

The magnetic high $2 \mathrm{~km}$ west of Little Cones has implications for the geometry of the Bare Mountain range-front fault. The anomaly appears to be structurally controlled because the strike of the anomaly inferred from the ground magnetic profiles and seen in the aeromagnetic data (fig. 2) parallels the strike of the Bare Mountain fault. Figures $6 \mathrm{a}$ and $6 \mathrm{c}$ show that a nearsurface magnetic source such as $100 \mathrm{~m}$ of Ammonia Tanks Tuff can account for the observed anomaly. The tuff, however, has to extend about $400 \mathrm{~m}$ east of the range-front fault as inferred by gravity modeling. Seismic-reflection data do not indicate whether another east-dipping fault is $400 \mathrm{~m}$ east of the Bare Mountain range-front fault. A fault $400 \mathrm{~m}$ east of the range-front fault is probably unlikely, because the normal fault east of the range-front Bare Mountain fault would most likely have kilometers of vertical displacement after the deposition of the Ammonia Tanks Tuff. Geologic mapping indicates that most of the displacement on normal faults in the Yucca Mountain area occurred before the deposition of the Ammonia Tanks Tuff (Carr, 1984), although recent mapping (C. Fridrich, U.S. Geological Survey, oral commun., 1994) indicates westward younging of extension across the Crater Flat basin. 
Figure $6 \mathrm{~b}$ shows a geometry that is consistent with one main east-dipping Bare Mountain fault. A combination of normally polarized sources can account for the double-peaked high: (1) $80 \mathrm{~m}$ of Topopah Spring Tuff west of the range-front fault and (2) normally polarized basalt east of the fault. The basalt would be related to the inferred normally polarized basaltic source for the aeromagnetic high south of Little Cones (fig. 2). The age of the inferred basaltic source is unknown but is most likely Miocene or younger (Langenheim, 1995b).

\section{Faulting in Crater Flat and Yucca Mountain}

The magnetic models indicate that the Solitario Canyon fault (station 980; fig. 3) has an offset of about $250 \mathrm{~m}$ of the Topopah Spring Tuff distributed along two strands of the fault (fig. 6). In order to match the position of the low, one must decrease the magnetization of the Topopah Spring Tuff by half for the block caught between the two strands of the fault. The decrease in magnetization could be caused by (1) alteration or (2) randomization of the remanent magnetization by intense brecciation in the fault zone. This result is consistent with previous modeling of magnetic data across the Solitario Canyon fault about $1.5 \mathrm{~km}$ to the north (Ponce and Langenheim, 1995). The $250 \mathrm{~m}$ estimate of offset is also consistent with the offset (up to $550 \mathrm{~m}$ ) of the pre-Tertiary contact imaged along line 2 by seismic-reflection methods (Brocher and others, 1995) if one accepts that the Solitario Canyon fault is a reactivated basement fault.

The models indicate little offset of the Topopah Spring Tuff, about $50 \mathrm{~m}$, along the Ghost Dance fault (station 1056, fig. 3). This result is somewhat greater than estimates from geologic mapping (about $30 \mathrm{~m}$, Spengler and 
others, 1993). Seismic-reflection data along Line 2 have been interpreted to indicate substantially more offset of the pre-Tertiary contact, about $1000 \mathrm{~m}$ in the vicinity of the Ghost Dance fault (Brocher and others, 1995). However, because magnetic data are sensitive to offsets of the Topopah Spring Tuff (fig. 5) and not to offsets of the pre-Tertiary contact, the magnetic data are also consistent with seismic-reflection data. These two sets of data, in conjunction with geologic data, indicate that most of the offset along the Ghost Dance fault occurred prior to the deposition of the Topopah Spring Tuff.

The models show numerous faults with small offsets in eastern Crater Flat and east of Yucca Mountain. The positioning of these faults is based on the gradients of ground magnetic anomalies. Some of these magnetically inferred faults correspond approximately to locations of mapped faults, such as the Windy Wash and Fatigue Wash faults (stations 810 and 865 respectively). The position of the Crater Flat fault based on the magnetic gradient method is about $200 \mathrm{~m}$ east of the inferred location of the fault (station 730). Offset on these faults is less than $250 \mathrm{~m}$ based on the modeling. The zone of closely-spaced faulting in eastern Crater Flat is consistent with disrupted character of the seismic reflection data in this area, in contrast to western Crater Flat (Brocher and others, 1995). The smoothness of the magnetic field, apart from the intense fluctuations at Little Cones and Red Cone, suggests either greater lateral continuity of volcanic units or deeper burial of the magnetic volcanic units. Deep burial of magnetic sources (e.g. volcanic units) greatly attenuates the resulting magnetic anomalies. Although seismic data (Mooney and Schapper, 1995; Brocher and others, 1995) and gravity modeling (Snyder and Carr, 1984; Langenheim, 1995a) indicate that the Tertiary tuff section is more deeply buried in western Crater Flat, the 
presence of basalt at shallow depths (approximately $360 \mathrm{~m}$ and probably 150 $\mathrm{m}$ ) and the absence of magnetic anomalies indicate that little structural disruption has occurred since their deposition. This is also consistent with seismic-reflection data (Brocher and others, 1995) that show little or no disruption of the 150-m-deep reflector inferred to be basalt.

\section{CONCLUSION}

Ground magnetic data along regional seismic line 2 show prominent anomalies associated with known faults and reveal a number of concealed faults in eastern Crater Flat. The models indicate that the broad magnetic high centered in Crater Flat cannot be caused by moderate thickening and doming of the Bullfrog Tuff, as previously proposed by Carr $(1984,1990)$. The source of the anomaly more likely lies below the Bullfrog Tuff and may be as deep as $5 \mathrm{~km}$. Possible sources for the magnetic high include altered argillite of the Mississippian-Upper Devonian Eleana Formation, an intrusion of Cretaceous or Tertiary age, or mafic sills. Simultaneous inversion of gravity and magnetic data may help determine whether an east-dipping fault $400 \mathrm{~m}$ east of the Bare Mountain fault exists and constrain estimates of offset for the Solitario Canyon and Ghost Dance faults. 


\section{REFERENCES CITED}

Baldwin, M.J., and Jahren, C.E., 1982, Magnetic properties of drill core and surface samples from the Calico Hills area, Nye County, Nevada: U.S. Geological Survey Open-File Report 82-536, 27 p.

Bath, G.D., 1968, Aeromagnetic anomalies related to remnant magnetism in volcanic rock, Nevada Test Site in Eckel, E.B., ed., Nevada Test Site: Geological Survey of America Memoir 110, p. 135-146.

Bath, G.D., Jahren, C.E., Rosenbaum, J.G., and Baldwin, M.J., 1983, Magnetic investigations, in Geologic and geophysical investigations of the Climax stock intrusive, Nevada: U.S. Geological Survey Open-File Report 83-377, p.40-77.

Bath, G.D., and Jahren, C.E., 1984, Interpretations of magnetic anomalies at a potential repository site located in the Yucca Mountain area, Nevada Test Site: U.S. Geological Survey Open-File Report 84-120, 40 p. (NNA.870323.0194)

Brocher, T.M., Carr, M.D., Fox, K.F., Jr., and Hart, P.E., 1993, Seismic reflection profiling across Tertiary extensional structures in the eastern Amargosa Desert, southern Nevada, Basin and Range province: Geological Society of America Bulletin, v. 105, p. 30-46.

Brocher, T.M., Hart, P.E., Hunter, W. Clay, and Langenheim, V.E., 1995, Hybrid-source seismic reflection profiling across Yucca Mountain, Nevada: Regional lines 2 and 3: U.S. Geological Survey Open-File Report 95-XXX, X p.

Carr, M.D., Waddell, S.J., Vick, G.S., Stock, J.M., Monsen, S.A., Harris, A.G., Cork, MW., and Byers, F.M., Jr., 1986, Geology of drill hole UE25p\#1: A test hole into pre-Tertiary rocks near Yucca Mountain, southern Nevada: U.S. Geological Survey Open-File Report 86-175, 87 p., 1 plate.

Carr, W.J., 1982, Volcano-tectonic history of Crater Flat, southwestern Nevada, as suggested by new evidence from drill hole USW VH-1 and vicinity: U.S. Geological Survey Open-File Report 82-457, 23 p.

Carr, W.J., 1984, Regional structural setting of Yucca Mountain, southwestern Nevada, and late Cenozoic rates of tectonic activity in part of the southwestern Great Basin, Nevada and California: U.S. Geological Survey Open-File Report 84-854, 109 p.

Carr, W.J., 1990, Styles of extension in the Nevada Test Site region, southern Walker Lane Belt; An integration of volcano-tectonic and detachment fault models in Wernicke, B.P., ed., Basin and Range extensional 
tectonics near the latitude of Las Vegas, Nevada: Geological Survey of America Memoir 176, p. 283-303.

Carr, W.J., and Parrish, L.D., 1985, Geology of drillhole USW VH-2, and structure of Crater Flat, southwestern Nevada: U.S. Geological Survey Open-File Report 85-475, 41 p.

Champion, D.E., 1991, Volcanic episodes near Yucca Mountain as determined by paleomagnetic studies at Lathrop Wells, Crater Flat, and Sleeping Butte, Nevada: Proceedings, High Level Radioactive Waste Management Conference, American Nuclear Society, p. 61-67.

Cordell, Lindrith, 1985, Techniques, applications, and problems of analytical continuation of New Mexico aeromagnetic data between arbitrary surfaces of very high relief [abs.]: Proceedings of the International Meeting on Potential Fields in Rugged Topography, Institute of Geophysics, University of Lausanne, Switzerland, Bulletin no. 7, p. 96-99.

Dobrin, M.B., and Savit, C.H., 1988, Introduction to Geophysical Prospecting (4th edition): McGraw-Hill Book Inc., New York, New York, 867 p.

Fridrich, C.J., Crowe, B.M., Hudson, M.R., Langenheim, V.E., and Thompson, G.A., 1994, Structural control of basaltic volcanism in a region of oblique extension, southwest Nevada volcanic field: Eos, Transactions, American Geophysical Union, v. 75, no. 44, p. 603.

Grauch, V.J.S., Kucks, R.P., and Bracken, R.E., 1993, Aeromagnetic data for western areas of the Pahute Mesa and Beatty $30 \times 60$ minute quadrangles, Nye County, Nevada: EROS Data Center Magnetic Tape A0804, 3 p.

Hamilton, 1988, Detachment faulting in the Death Valley region, California and Nevada, in Carr, M.D., and Yount, J.C., eds., Geologic and hydrologic investigations of a potential nuclear waste disposal site at Yucca Mountain, southern Nevada: U.S. Geological Survey Bulletin 1790, p. 5185.

Johnson, L.R., Parker, P.B., Williams, K.H., and Romero, A.E., 1995, Gravity and magnetic data on regional seismic lines: Lawrence Berkeley Laboratory Summary Report 0BB01-LBNL, $21 \mathrm{p}$.

Kane, M.F., and Bracken, R.E., 1983, Aeromagnetic map of Yucca Mountain and surrounding regions, southwest Nevada: U.S. Geological Survey Open-File Report 83-616, 19 p., 1 plate.

Langenheim, V.E., 1995a, Constraints on the structure of Crater Flat, southwest Nevada, derived from gravity and magnetic data: U.S. Geological Survey Circular, in press. 
Langenheim, V.E., 1995b, Magnetic and gravity studies of buried volcanic centers in the Amargosa Desert and Crater Flat, southwest Nevada: U.S. Geological Survey Open-File Report 95-564, 37 p.

Langenheim, V.E., Carle, S.F., Ponce, D.A., and Phillips, J.D., 1991, Revision of an aeromagnetic survey of the Lathrop Wells area, Nevada: U.S.

Geological Survey Open-File Report 91-46, 12 p., 6 fig., 3 plates, 1 magnetic tape.

Majer, E.L., and Karageorgi, Eleni, 1994, Ghost Dance surface reflection profiles: Lawrence Berkeley Laboratory Milestone Report 3GGF240M, 16 p.

McKay, E.J., and Williams, W.P., 1964, Geology of the Jackass Flats quadrangle, Nye County: U.S. Geological Survey Geologic Quadrangle GQ-368, scale 1:24,000.

Monsen, S.A., Carr, M.D., Reheis, Marith, and Orkild, P.J., 1992, Geologic map of Bare Mountain, Nye County, Nevada: U.S. Geological Survey Miscellaneous Investigations Map I-2201, scale 1:24,000, 6 p.

Mooney, W.D., and Schapper, S.G., 1995, Seismic refractions studies in Oliver, H.W., Ponce, D.A., and Hunter, W. Clay, eds., U.S. Geological Survey Open-File Report 95-74, variously paged.

Muller, D.C., and Kibler, J.E., 1984, Preliminary analysis of geophysical logs from drill hole UE-25p\#1, Yucca Mountain, Nye County, Nevada: U.S. Geological Survey Open-File Report 84-649, 14 p. (HQS.880517.1353)

Oliver, H.W., and Fox, K.F., 1993, Structure of Crater Flat and Yucca Mountain, southeastern (sic) Nevada, as inferred from gravity data: American Nuclear Society Proceedings of the Fourth Annual International Conference on High Level Nuclear Waste Management, April 26-30, 1993, Las Vegas, NV, v. 2, p. 1812-17.

Ponce, D.A., Langenheim, V.E., and Sikora, R.F., 1993, Gravity and magnetic data of Midway Valley, southwest Nevada: U.S. Geological Survey OpenFile Report 93-540-A, 7 p. (NNA.940418.0157)

Ponce, D.A., and Langenheim, V.E., 1995, Gravity and magnetic investigations of the Ghost Dance and Solitario Canyon faults, Yucca Mountain, Nevada: U.S. Geological Survey Open-File Report 95-521, 26 p.

Rosenbaum, J.G., and Snyder, D.B., 1985, Preliminary interpretation of paleomagnetic and magnetic property data from drill holes USW G-1, G-2, G-3, and VH-1 and surface localities in the vicinity of Yucca Mountain, Nye County, Nevada: U.S. Geological Survey Open-File Report 85-49, 73 
p.

Sawyer, D.A., Fleck, R.J., Lanphere, M.A., Warren, R.G., Broxton, D.E., and Hudson, M.R., 1994, Episodic caldera volcanism in the Miocene southwestern Nevada volcanic field: Revised stratigraphic framework, ${ }^{40} \mathrm{Ar} /{ }^{39} \mathrm{Ar}$ geochronology, and implications for magmatism and extension: Geological Society of America Bulletin, v. 106, p. 1304-1318.

Scott, R.B., and Bonk, J., 1984, Preliminary geologic map of Yucca Mountain, Nye County, Nevada with geologic sections: U.S. Geological Survey Open-File Report 84-494, scale 1:12,000.

Simonds, F.W., Whitney, J.W., Fox, K.F., Ramelli, A.R., Yount, J.C., Carr, M.D., Menges, C.M., Dickerson, R.P., and Scott, R.B., 1995, Map showing fault activity in the Yucca Mountain area, Nye County, Nevada: U.S. Geological Survey report.

Snyder, D.B., and Carr, W.J., 1984, Interpretation of gravity data in a complex volcano-tectonic setting, southwest Nevada: Journal of Geophysical Research, v. 89, p. 10,193-10,206.

Spengler, R.W., Braun, C.A., Linden, R.M., Martin, L.G., Ross-Brown, D.M., and Blackburn, R.L., 1993, Structural character of the Ghost Dance fault, Yucca Mountain, Nevada: American Nuclear Society Proceedings of the Fourth Annual International Conference on High Level Radioactive Waste Management, v. 1, p. 653-659.

Swadley, W.C., and Carr, W.J., 1987, Geologic map of the Quaternary and Tertiary deposits of the Big Dune quadrangle, Nye County, Nevada, and Inyo County, California: U.S. Geological Survey Miscellaneous Investigations Map I-1767, scale 1:48,000.

Swadley, W.C., and Parrish, L.D., 1988, Surficial geological map of the Bare Mountain quadrangle, Nye County, Nevada: U.S. Geological Survey Miscellaneous Investigations Map I-1826, scale 1:48,000.

U.S. Geological Survey, 1979, Aeromagnetic map of the Timber Mountain area, Nevada: U.S. Geological Survey Open-File Report 79-587, scale 1:62,500.

U.S. Geological Survey, 1984, A summary of geologic studies through January 1, 1983, of a potential high-level radioactive waste repository site at Yucca Mountain, southern Nye County, Nevada: U.S. Geological Survey OpenFile Report 84-792, 103 p. (NNA.891009.0305)

Whitfield, M.S., Jr., Thordarson, William, and Eshom, E.P., 1984, Geohydrologic and drill-hole data for test well USW H-4, Yucca 
Mountain, Nye County, Nevada: U.S. Geological Survey Open-File Report 84-449, 39 p.

Note: Parenthesized numbers following each cited reference are for U.S. Department of Energy Office of Civilian Radioactive Waste Management Records Management purposes only and should not be used when ordering the publication. 
Table 1.-Geologic names and symbols ${ }^{1}$

\begin{tabular}{lll}
\hline Name of unit & Symbol \\
\hline Alluvium and colluvium & Quaternary & \\
\hline
\end{tabular}

Pliocene

\begin{tabular}{|c|c|}
\hline 3.7 Ma basalt & $\mathrm{Tb}^{\mathrm{a}}$ \\
\hline \multicolumn{2}{|c|}{ Miocene $^{2}$} \\
\hline 10.5 Ma basalt & $\mathrm{Tb}^{\mathrm{b}}$ \\
\hline \multicolumn{2}{|l|}{ Timber Mountain Group } \\
\hline Ammonia Tanks Tuff & Tma \\
\hline Rainier Mesa Tuff & $\operatorname{Tmr}$ \\
\hline \multicolumn{2}{|l|}{ Paintbrush Group } \\
\hline Tiva Canyon Tuff & Tpc \\
\hline Yucca Mountain Tuff* & Tpy \\
\hline Pah Canyon Tuff* & Tpp \\
\hline Topopah Spring Tuff & Tpt \\
\hline Calico Hills Formation & Tht \\
\hline \multicolumn{2}{|l|}{ Crater Flat Group } \\
\hline Prow Pass Tuff & Tcp \\
\hline Bullfrog Tuff & $\mathrm{Tcb}$ \\
\hline Tram Tuff & Tct $=$ \\
\hline Lavas and Flow Breccias* & Tll \\
\hline Lithic Ridge Tuff & Tlr \\
\hline Older Tuffs & $\mathrm{Tt}$ \\
\hline \multicolumn{2}{|c|}{ Paleozoic } \\
\hline Paleozoic rocks, undifferentiated & $\mathrm{Pz}$ \\
\hline
\end{tabular}

'(modified from Sawyer and others, 1994)

${ }^{2}$ Includes bedded tuff at base of most units

*Not included in models because stratigraphic logs from nearby wells indicate absence or very thin. 
Table 2.-Magnetic properties of rock units used in the models. ${ }^{1}$

\begin{tabular}{|lccc|}
\hline Unit & $\begin{array}{c}\text { Declination } \\
\text { deg }\end{array}$ & $\begin{array}{c}\text { Inclination }^{2} \\
\text { deg }\end{array}$ & $\begin{array}{c}\text { Magnetization } \\
\text { (2/m }\end{array}$ \\
\hline $\mathrm{Qac}$ & 0 & 0 & 0 \\
$\mathrm{~Tb}^{\mathrm{a}}$ & 178 & -64 & 10 \\
$\mathrm{~Tb}^{\mathrm{b}, 3}$ & 180 & -55 & 10 \\
$\mathrm{Tma}$ & 0 & 59 & 0.58 \\
$\mathrm{Tmr}{ }^{4}$ & 168 & -55 & $0.8-2.7$ \\
$\mathrm{Tpc}$ & 169 & -23 & 0.94 \\
$\mathrm{Tpt}$ & 322 & 52 & 1.3 \\
$\mathrm{Tht}$ & 6 & 56 & 0.11 \\
$\mathrm{Tcp}$ & -4 & 50 & 0.26 \\
$\mathrm{Tcb}$ & 12 & 41 & 1.7 \\
$\mathrm{Tct}$ & 131 & -30 & 1.2 \\
$\mathrm{Tlr}$ & 251 & 62 & 0.22 \\
$\mathrm{Tt}$ & 50 & 60 & 0.3 \\
$\mathrm{Pz}$ & 0 & 0 & 0 \\
\hline
\end{tabular}

${ }^{1}$ Values were derived from borehole samples, borehole logs, and surface samples. Data modified from Rosenbaum and Snyder (1985), Bath and Jahren (1984), M. R. Hudson (USGS, written commun., 1994), and Champion (1991).

${ }^{2}$ Total declination, inclination, and magnetization.

${ }^{3}$ Expected direction from dipole model of magnetic field; amplitude of magnetization assumed to be same as that of $\mathrm{Tb}^{\mathrm{a}}$.

${ }^{4}$ Remanent declination, inclination, and magnetization. 
Table 3.-Thickness in meters of rock units in various drill holes ${ }^{1,2}$

\begin{tabular}{|ccccccccc|}
\hline Symbol & VH-1 & VH-2 & WT-7 & WT-2 & H-4 & UZ-16 & H-6 & p\#1 \\
\hline Qac & 29 & 360 & 12 & 18 & - & 12 & 9 & 39 \\
Tb $^{\mathrm{a}}$ & $14^{3}$ & - & - & - & - & - & - & - \\
Tb $^{\mathrm{b}}$ & - & 30 & - & - & - & - & - & - \\
Tma & - & $54^{4}$ & - & - & - & - & - & - \\
Tmr & - & - & - & - & - & - & - & 16 \\
Tpc & 110 & 165 & 120 & 82 & 62 & 52 & 73 & 26 \\
Tpy & - & - & - & - & - & - & - & - \\
Tpp & - & - & - & - & - & - & 9 & - \\
Tpt & 302 & 357 & 319 & 344 & 335 & 302 & 401 & 300 \\
Tht & - & - & 41 & 88 & 96 & 87 & 9 & 55 \\
Tcp & 54 & 75 & 11 & 142 & 194 & 61 & 89 & 122 \\
Tcb & 141 & 5 & - & - & 113 & - & 159 & 132 \\
Tct & - & - & - & - & 343 & - & 190 & 183 \\
Tll & - & - & - & - & - & - & 253 & - \\
Tlr & - & - & - & - & 55 & - & 90 & 194 \\
Tt & - & - & - & - & - & - & - & 177 \\
Pz & - & - & - & - & - & - & - & 561 \\
\hline
\end{tabular}

${ }^{1}$ Includes bedded tuffs at base of most volcanic units.

${ }^{2}$ Data modified from R. Spengler (WT-logs, USGS, written commun., 1994), Muller and Kibler (1984), D. Buesch (UZ-16 log, USGS, written commun., 1994), Whitfield and others (1984), Carr (1982), and Carr and Parrish (1985).

${ }^{3}$ Underlain by $102 \mathrm{~m}$ of Qac.

${ }^{4}$ Underlain by $87 \mathrm{~m}$ of Miocene landslide breccia deposits. 


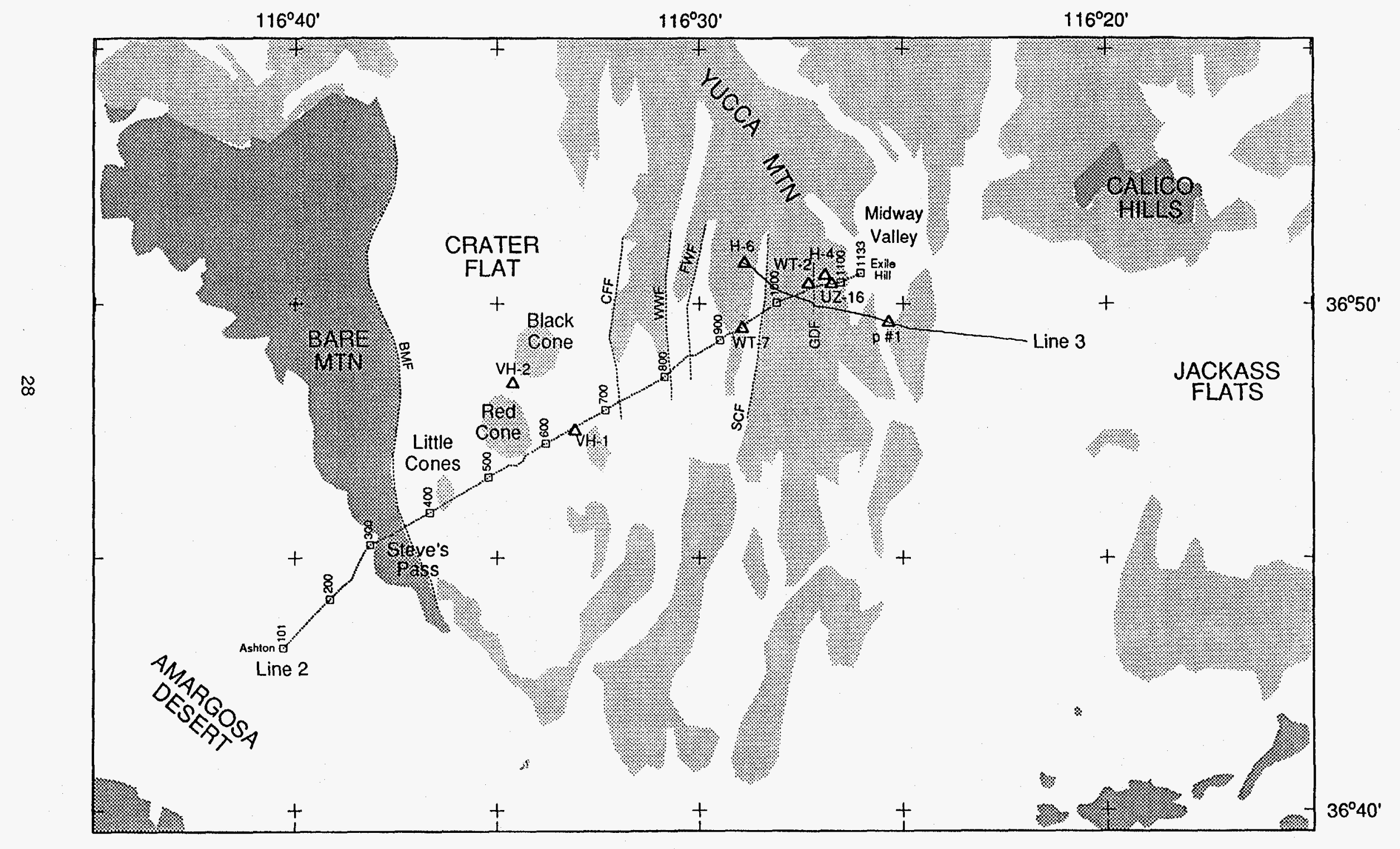

\section{$2-4 \quad-\quad-10 \quad 10 \mathrm{kM}$}

Figure 1. Geologic map of the study area. Dark shaded areas denote outcrops of Precambrian and Paleozoic sedimentary and metamorphic rocks; lightly shaded areas, Tertiary and Quaternary volcanic rocks; white areas, Tertiary and Quaternary alluvium. Triangles show locations of selected drill holes; boxes show location of beginning and ending point and every 100th surveyed point; dots are actual surveyed point locations. Dashed lines denote faults mentioned in text: BMF, Bare Mountain fault; CFF, Crater Flat fault; WWF, Windy Wash fault; FWF, Fatigue Wash fault; SCF, Solitario Canyon fault; GDF, Ghost Dance fault. 


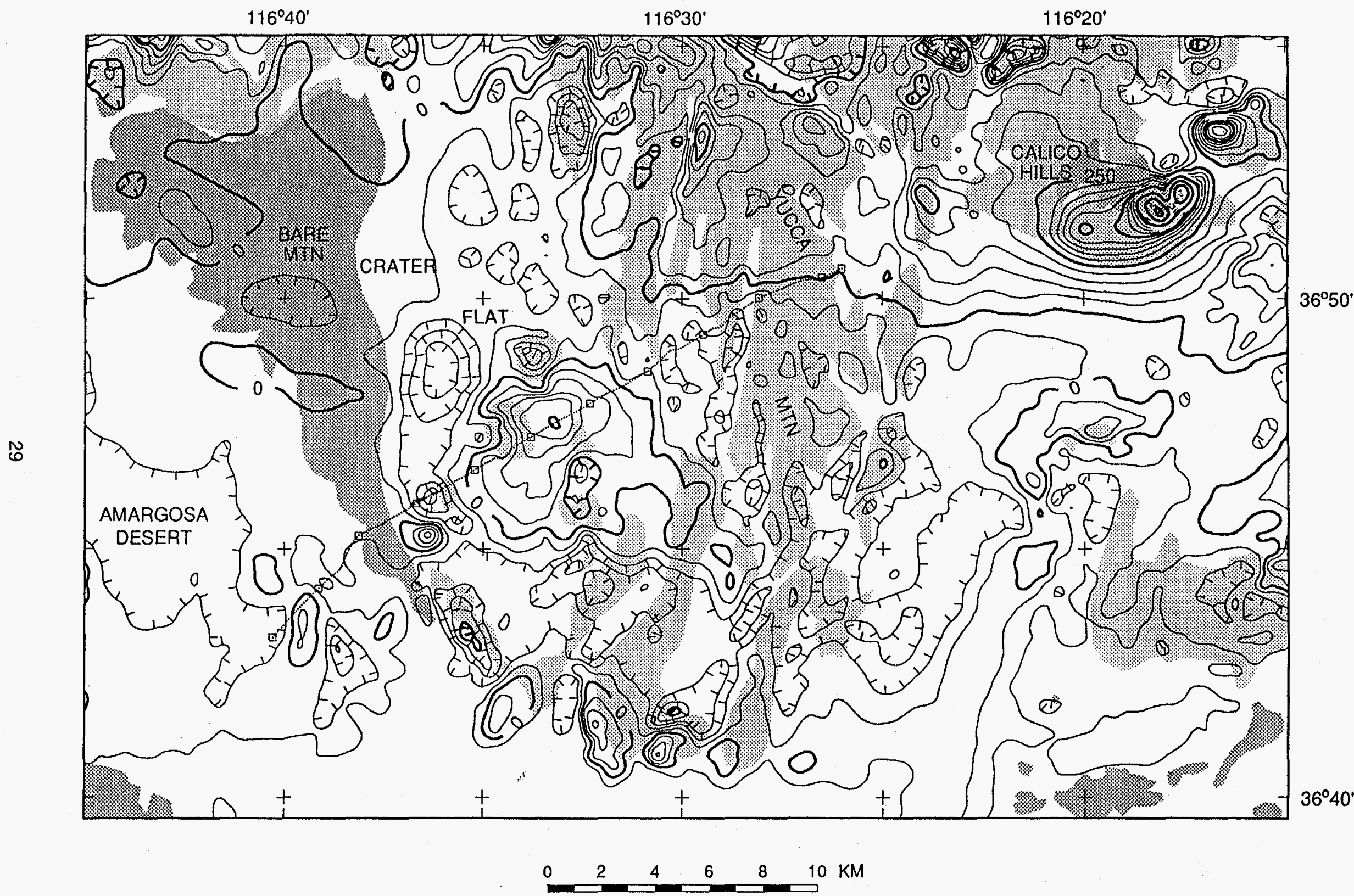

Figure 2. Aeromagnetic map of the study area. Contour interval, $50 \mathrm{nT}$. Dark shaded areas denote outcrops of Precambrian and Paleozoic sedimentary and metamorphic rocks; lightly shaded areas, Tertiary and Quaternary volcanic rocks; white areas, Tertiary and Quaternary alluvial deposits. Dots are actual surveyed points along line 2; boxes show location of beginning and ending points and every 100 th surveyed point location. 


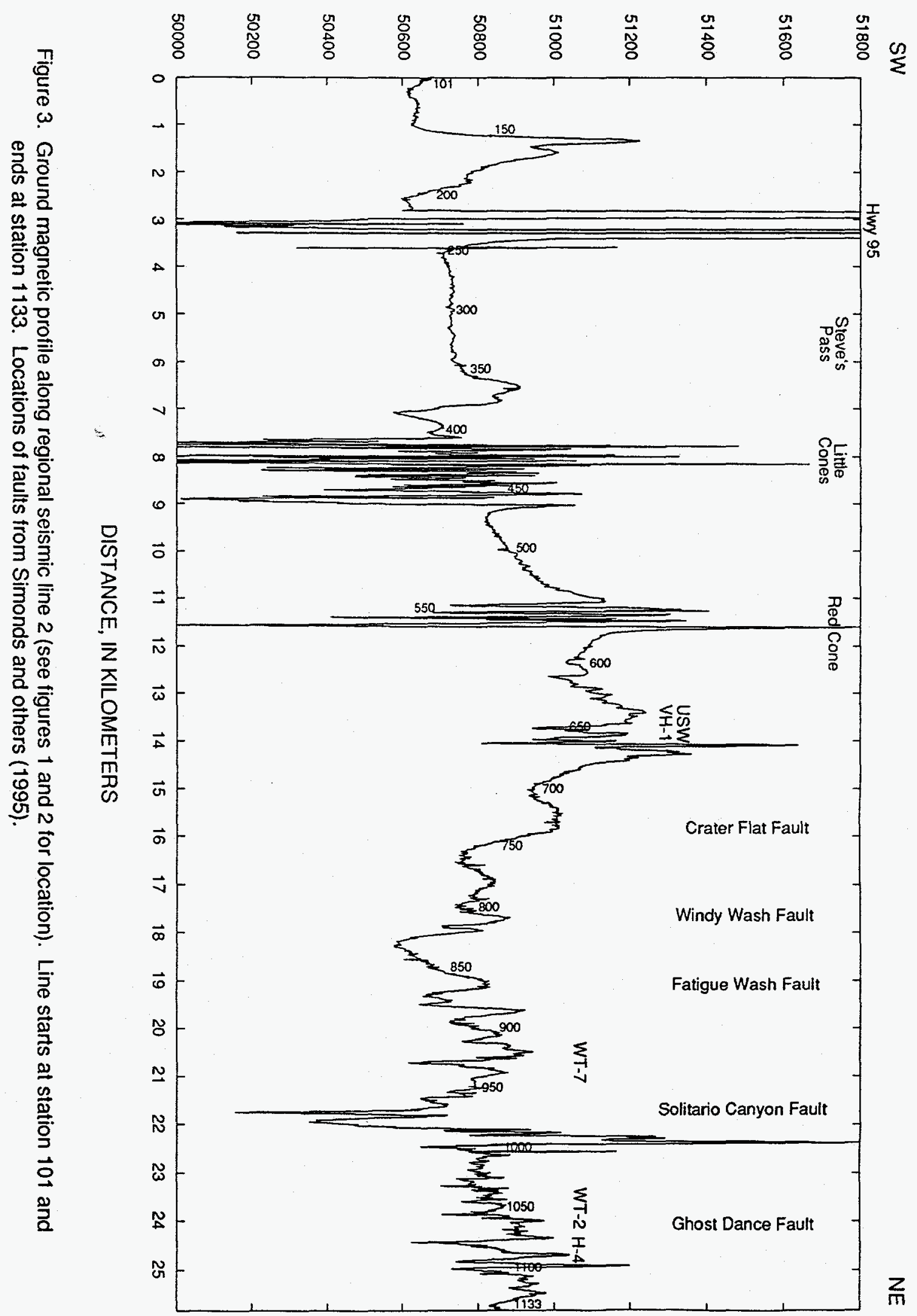




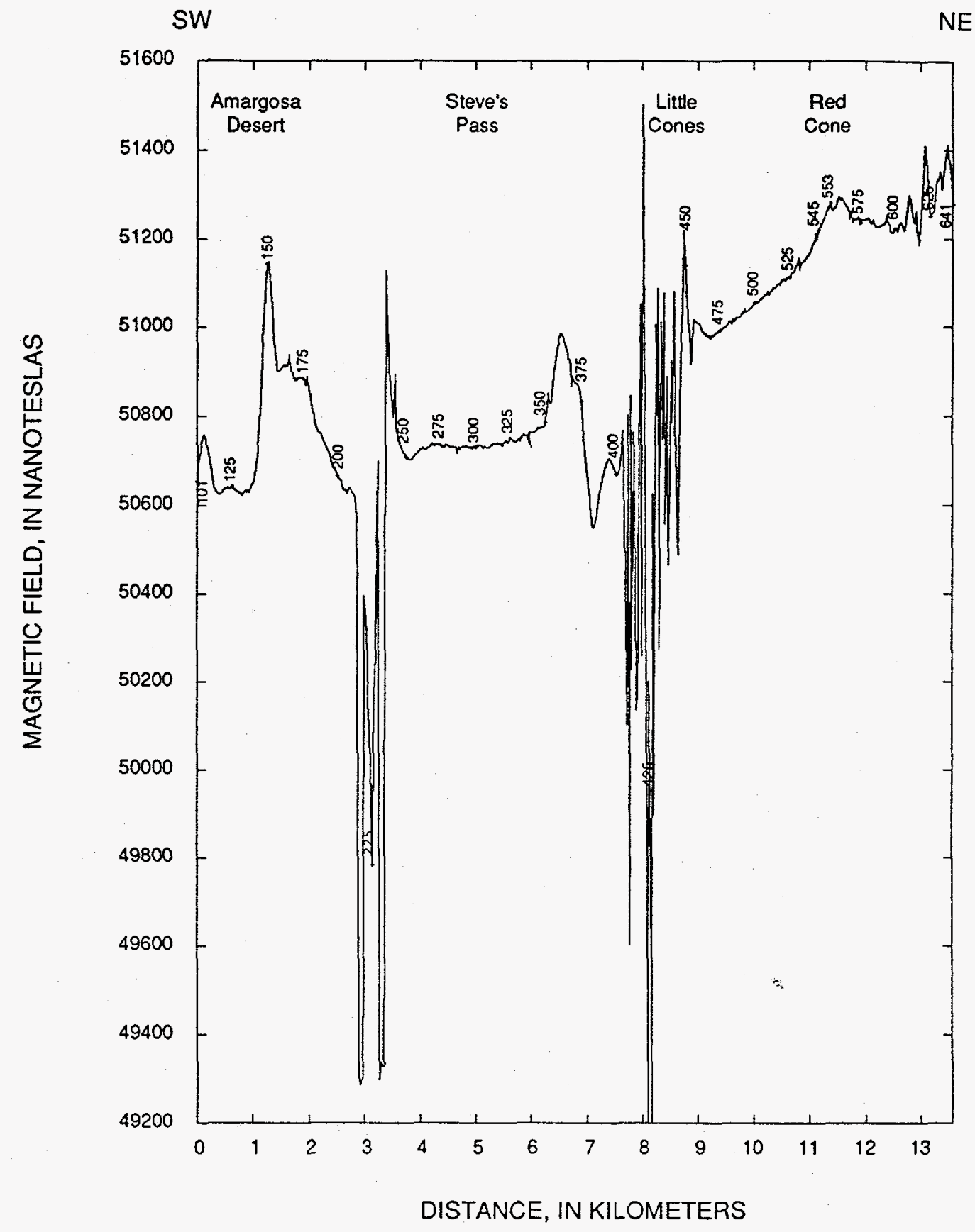

Figure 4a. Ground magnetic data along profile located approximately $100 \mathrm{~m}$ southeast of seismic profile. Line starts at station 101 and ends at station 641. 


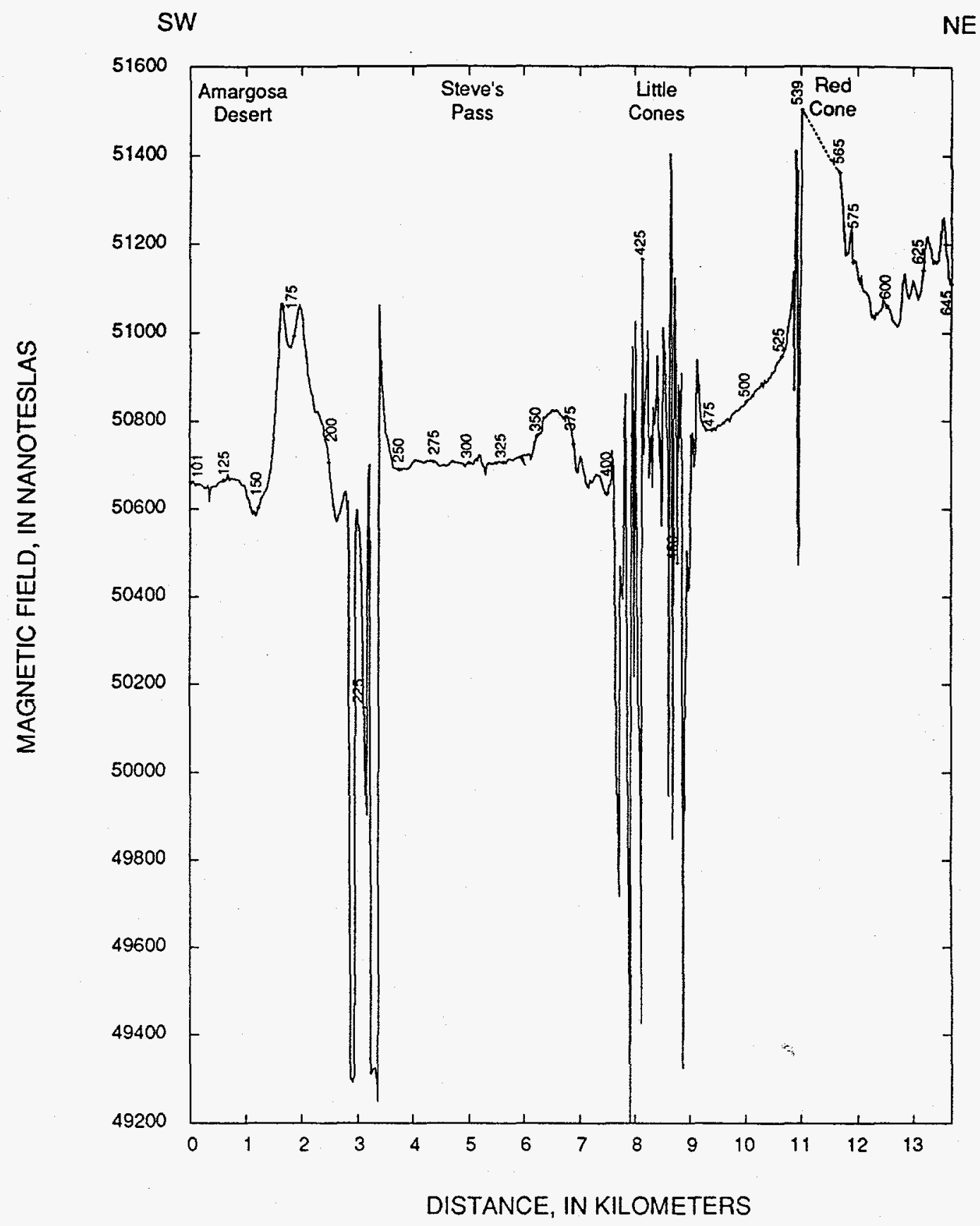

Figure 4b. Ground magnetic data along profile located approximately $100 \mathrm{~m}$ northwest of seismic profile. Line starts at station 101 and ends at station 645 . No data were collected between stations 539 and 565 because of extreme fluctuations in the magnetic field. 

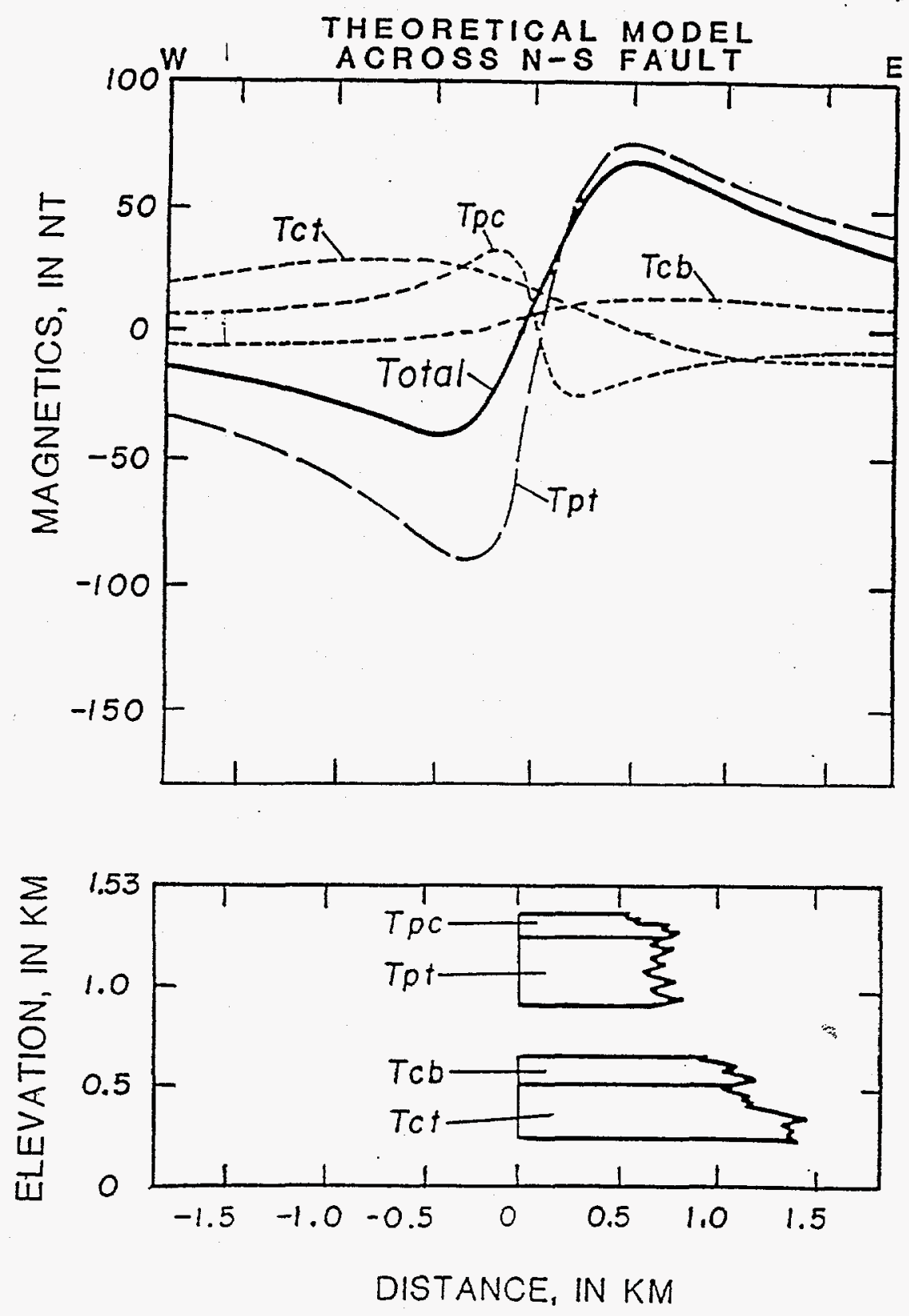

Figure 5. Theoretical magnetic anomaly from vertical offset of north-south trending fault (from Bath and Jahren, 1984). Geologic units and their modeled properties are described in tables 1 and 2 , respectively. 


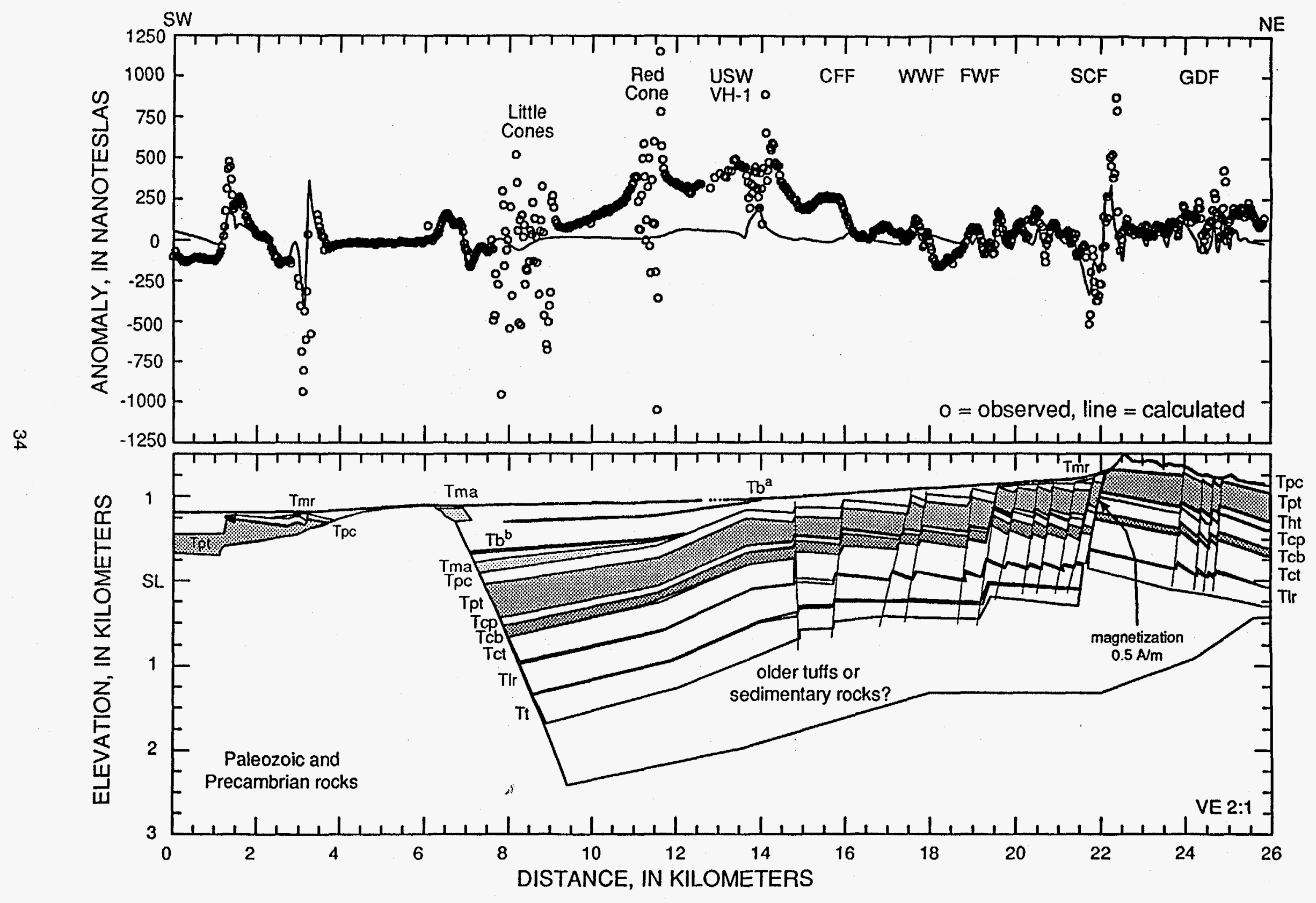

Figure 6a. Magnetic model along seismic-reflection profile line 2 showing that moderate doming and thickening of the Bullfrog Tuff (Tcb) is not sufficient to produce magnetic high centered over Crater Flat. 


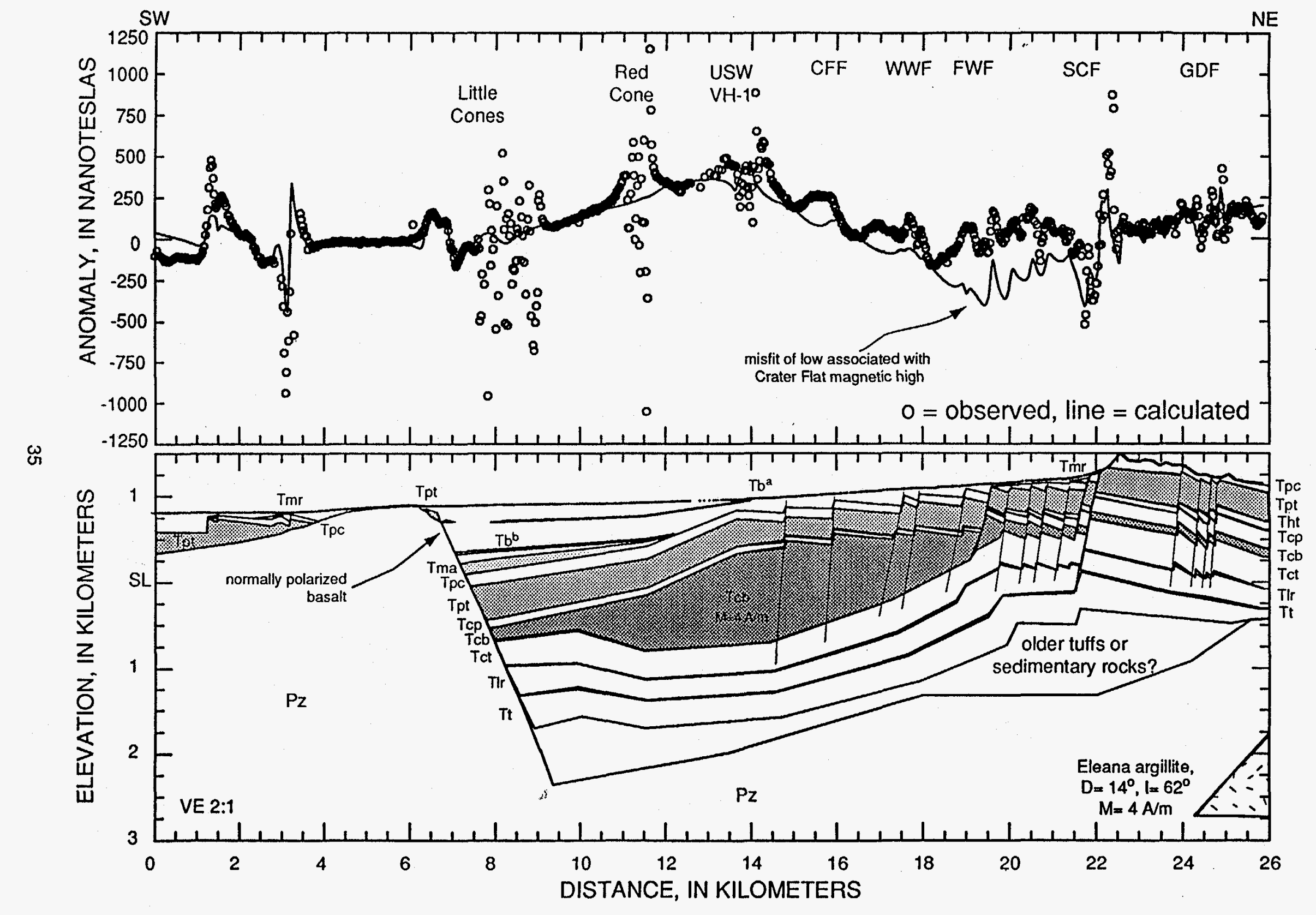

Figure $6 \mathrm{~b}$. Magnetic model along seismic-reflection profile line 2 illustrating the amount of thickening and increase in magnetization of the Bullfrog Tuff $(\mathrm{Tcb})$ required to match the amplitude of the observed magnetic high centered over Crater Flat. 

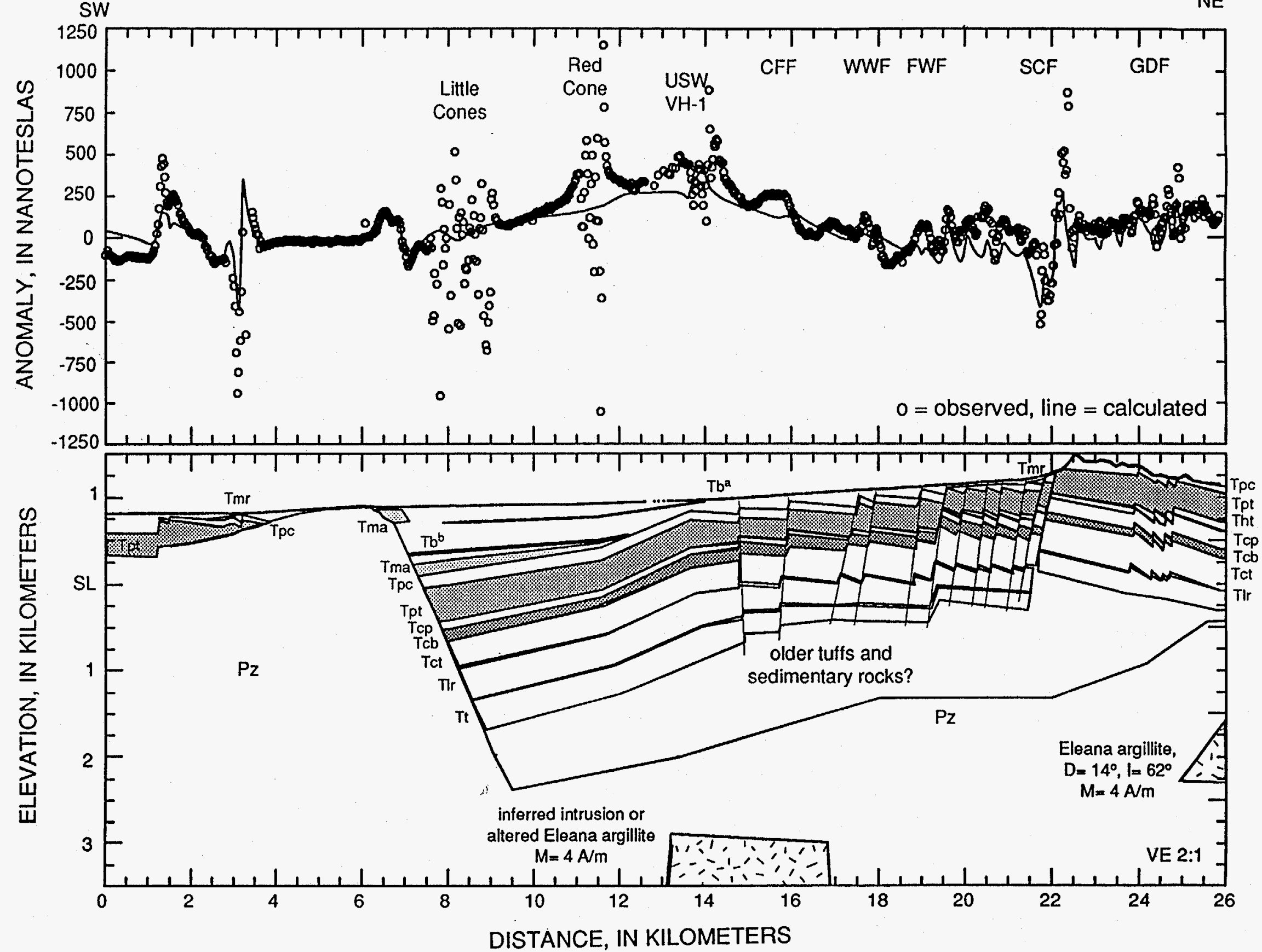

Figure 6c. Magnetic model along seismic-reflection profile line 2 showing that a strongly magnetic body within the pre-Tertiary basement can create an anomaly comparable to that observed over central Crater Flat. 